\title{
UNDANG-UNDANG DAN JAMINAN POLITIK PEREMPUAN
}

\section{Oleh: M. Jamil ${ }^{1}$}

Perempuan dalam konteks gender didefinisikan sebagai sifat yang melekat pada seseorang untuk menjadi feminism (bersifat kewanitaan). Dalam Kamus Besar Bahasa Indonesia, kata perempuan bermakna (1) orang (manusia) yang mempunyai puki, dapat menstruasi, hamil, melahirkan anak, dan menyusui; wanita; (2) istri; bini: - nya sedang hamil; (3) betina (khusus untuk hewan), sedangkan kata wanita bermakna perempuan dewasa: kaum — , kaum putri (dewasa).

Sebelum lahirnya Negara Kesatuan Republik Indonesia, peran perempuan sudah dalam dunia politik sudah ada, karena Sejarah Indonesia mencatat seorang tokoh bernama Gayatri Rajapatni (Ratu di atas segala Ratu) yang wafat pada tahun 1350 yang diyakini sebagai perempuan di balik kebesaran Kerajaan Majapahit. Majapahit merupakan kerajaan Hindu-Budha yang di mata banyak orang tidak mungkin memberikan ruang bagi perempuan untuk berpolitik. Tetapi hasil kajian yang dilakukan oleh mantan Dubes Canada untuk Indonesia (Earl Dark, ia juga sebagai sejarawan) membuktikan, bahwa puncak kejayaan Majapahit tercapai karena peran sentral Gayatri, istri Raden Widjaya, ibunda ratu ketiga Majapahit, Tribhuwanatungga-dewi, sekaligus nenek dari Hayamwuruk, raja terbesar di sepanjang sejarah Kerajaan Majapahit. Gayatri tidak pernah menjabat resmi sebagai ratu, tetapi peran politiknya telah melahirkan generasi politik yang sangat luar biasa di Nusantara kala itu.

Di era Kolonialisme Belanda kita mengenal RA Kartini, ia lahir sebagai pemimpin perempuan yang memperjuangkan kebebasan dan peranan perempuan melalui emansipasi dalam bidang pendidikan. Berkat pemikiran-pemikiran yang

\footnotetext{
${ }^{1}$ Ketua Umum Pusat Studi Mahasiswa Pascasarjana (PUSMAJA) Mbojo-Yogyakarta Periode 2015-2017 | | Ketua II Bagian Eksternal Dewan Pimpinan Cabang Perhimpunan Mahasiswa Hukum Indonesia Daerah Istimewa Yogyakarta (DPC PERMAHI DIY) Periode 2012-2014 | Email: jamilncera@gmail.com | FB/Youtube/IG/Twitter: @MJAMILSH | Website: http://www.mjamil.my.id.
} 
ia lahirkan, sehingga sampai saat ini pemikirannya masih menjadi bahan kajian para Kartini masa kini. Tokoh Supeni, dikenal sebagai politikus wanita yang menduduki berbagai jabatan penting di Indonesia. Ia pernah menjabat sebagai anggota DPR sekaligus anggota Konstituante melalui partai PNI. Sebagai diplomat, ia pernah menjabat sebagai duta besar luar biasa dan berkuasa penuh untuk Amerika Serikat dan duta besar keliling di zaman Presiden Soekarno. Sebagai salahsatu contoh lagi yakni Dra. Khofifah Indar Parawansa, ia adalah Menteri Negara Pemberdayaan Perempuan pada Kabinet Persatuan Nasional. Adapun karir politiknya yakni: (1) Pimpinan Fraksi Partai Persatuan Pembangunan DPR RI (1992-1997); (2) Pimpinan Komisi VIII DPR RI (19951997); (3) Anggota Komisi II DPR RI (1997-1998); (4) Wakil Ketua DPR RI (1999); (5) Sekretaris Fraksi Partai Kebangkitan Bangsa MPR RI (1999); (6) Menteri Negara Pemberdayaan Perempuan (1999-2001); (7) Kepala Badan Koordinasi Keluarga Berencana Nasional (1999-2001); (8) Ketua Komisi VII DPR RI (2004-2006); (9) Ketua Fraksi Kebangkitan Bangsa MPR RI (20042006); (10) Anggota Komisi VII DPR RI (2006).

Undang-Undang Dasar Negara Republik Indonesia Tahun 1945 pada Pasal 1 ayat (2) menyatakan bahwa "kedaulatan berada di tangan rakyat dan dilaksanakan menurut Undang-Undang Dasar". Makna dari "kedaulatan berada di tangan rakyat" adalah bahwa rakyat memiliki kedaulatan, tanggung jawab, hak dan kewajiban untuk secara demokratis memilih pemimpin yang akan membentuk pemerintahan guna mengurus dan melayani seluruh lapisan masyarakat, serta memilih wakil rakyat untuk mengawasi jalannya pemerintahan. Perwujudan kedaulatan rakyat dilaksanakan melalui Pemilu secara langsung sebagai sarana bagi rakyat untuk memilih wakilnya yang akan menjalankan fungsi melakukan pengawasan, menyalurkan aspirasi politik rakyat, membuat undang-undang sebagai landasan bagi semua pihak di Negara Kesatuan Republik Indonesia dalam menjalankan fungsi masing-masing, serta merumuskan anggaran pendapatan dan belanja untuk membiayai pelaksanaan fungsi-fungsi tersebut. Sesuai dengan ketentuan Pasal 22E Undang-Undang Dasar Negara Republik Indonesia Tahun 1945, Pemilu untuk memilih anggota Dewan Perwakilan Rakyat, Dewan 
Perwakilan Daerah, dan Dewan Perwakilan Rakyat Daerah diselenggarakan berlandaskan asas langsung, umum, bebas, rahasia, jujur, dan adil setiap lima tahun sekali. Pemilu diselenggarakan dengan menjamin prinsip keterwakilan, yang artinya setiap orang Warga Negara Indonesia dijamin memiliki wakil yang duduk di lembaga perwakilan yang akan menyuarakan aspirasi rakyat di setiap tingkatan pemerintahan, dari pusat hingga ke daerah. Pemilu yang terselenggara secara langsung, umum, bebas, rahasia, jujur, dan adil merupakan syarat mutlak untuk mewujudkan wakil rakyat yang berkualitas, dapat dipercaya, dan dapat menjalankan fungsi kelembagaan legislatif secara optimal. Penyelenggaraan Pemilu yang baik dan berkualitas akan meningkatkan derajat kompetisi yang sehat, partisipatif, dan keterwakilan yang makin kuat dan dapat dipertanggungjawabkan.

Peran perempuan dan laki-laki pada dasarnya sama, itu juga telah diamanatkan oleh konstitusi kita Undang-undang Dasar Tahun 1945, pada penggalan Pasal 28D ayat 1 berbunyi "setiap orang berhak atas perlakuan yang sama di hadapan hukum". Itu berarti baik laki-laki maupun perempuan pada dasarnya sama dihadapan hukum, berperan dalam politik, berpran dalam dunia pendidikan, berperan dalam dunia kesehatan, dan berperan dalam bentuk apa pun pemi kemajuan dan keutuhan negara tercinta yakni Negara Nesatuan Republik Indonesia. Lebih lanjut dalam Pasal 28D ayat (3) Undang-undang Dasar Tahun 1945 amandemen kedua mengamanatkan "setiap warga negara berhak memperoleh kesempatan yang sama dalam pemerintahan". Pastilah kita kenal tokoh perempuan yang pertama menjadi Presiden Perempuan di Indonesia, ia adalah Ibu Megawati Soekarnoputri, menteri juga banyak dari kalangan perempuan, salahsatunya Ibu Siti Fadilah Supari, pernah menjadi Mentri Kesehatan Republik Indonesia, ditingkat Pemerintah Provinsi, pemerintah Kabupaten, bahkan yang jadi Walikota dari kalangan perempuan bisa dibilang banyak jumlahnya di Indonesia ini. Mengenai persamaan yang di amanahkan Undang-undang Dasar Tahun 1945 ada juga di Pasal 28H ayat (2) yakni berbunyi "setiap orang berhak mendapat kemudahan dan perlakuan khusus untuk memperoleh kesempatan dan manfaat yang sama guna mencapai persamaan dan 
keadilan". Jadi, tidak ada yang bisa menyangkal bahwasannya permpuan juga bisa berperan dalam berbagai bidang yang biasananya dilakukan para lelaki, karena itu semua sudah dijamin dan di khidmad oleh konstitusi kita serta dalam kenyataannya juga telah terbukti.

Didalam bingkai kehidupan sosial dan politik masyarakat Indonesia secara umum memberikan ruang yang luas dan ramah bagi kaum perempuan untuk berkiprah dalam politik, termasuk menjadi pemimpin. Bahkan kesempatan ini terus diberikan, termasuk penetapan kuota $30 \%$ perempuan di parlemen melalui Undang-Undang Nomor 8 Tahun 2012 tentang Pemilihan Umum Anggota Dewan Perwakilan Rakyat, Dewan Perwakilan Daerah, dan Dewan Perwakilan Rakyat Daerah. Dari perspektif historis, nampak bahwa sepanjang sejarah Indonesia, pemimpin perempuan telah muncul silih-berganti. Rahim Ibu Indonesia telah membuktikan diri sebagai rahim yang subur bagi lahirnya para pemimpin perempuan terkemuka di bumi pertiwi, sungguh mulia jasamu pasa ibu, karena engan tangan lebutmu engkau rawat anak-anak mu hingga besar dan berprestasi, karena dengan kasih sayang mu engkau didik anak-anakmu jadi seorang pemimpin.

Adanya partai politik merupakan salah satu wujud partisipasi masyarakat yang penting dalam mengembangkan kehidupan demokrasi yang menjunjung tinggi kebebasan, kesetaraan, kebersamaan, dan kejujuran. Dalam artian menjunjung tinggi "kebebasan" dalam berucap, bersikap, berbuat, bertingkah serta berpolitik. Menjunjung tinggi "kesetaraan" dalam bentuk apapun, termasuk kesetaraan dalam mengambil bagian dan berkompetisi dalam dunia politik. Menjunjung tinggi kebersamaan dalam membangun bangsa, agar bangsa indonesia menjadi bangsa yang besar, bangsa yang adil, bangsa yang bermartabat serta menjadikan bangsa yang mandiri, bagian ini tidak hanya dilakukan oleh para laki-laki, namun para perempuan pun harus turut andil didalamnya. Menjunjung tinggi "kejujuran", kejujuran itu sangat-sangat tinggi nilainya di mata masyarakat, karena kalau kita telah jujur maka kita akan dipercayai selamanya, para perempuan pasti telah mengenyam nilai-nilai kejujuran itu, karena hati dan jiwa 
perempuan itu lembut dan selalu mengutamakan hati nurani dalam setiap tingkahlakunya.

Undang-Undang Nomor 8 Tahun 2012 tentang Pemilihan Umum Anggota Dewan Perwakilan Rakyat, Dewan Perwakilan Daerah, dan Dewan Perwakilan Rakyat Daerah, pada Pasal 8 Ayat (2) berbunyi "partai politik yang tidak memenuhi ambang batas perolehan suara pada Pemilu sebelumnya atau partai politik baru dapat menjadi Peserta Pemilu setelah memenuhi persyaratan”. Pasal 8 Ayat (2) Poin e berbunyi “menyertakan sekurang-kurangnya 30\% (tiga puluh persen) keterwakilan perempuan pada kepengurusan partai politik tingkat pusat". Jadi, keterwakilan perempuan dalam konstitusi itu telah dijamin. Pada Pasal 15 Poin d berbunyi "surat keterangan dari pengurus pusat partai politik tentang penyertaan keterwakilan perempuan sekurang-kurangnya 30\% (tiga puluh persen) sesuai dengan ketentuan peraturan perundang-undangan. Yang dimaksud dengan "penyertaan keterwakilan perempuan sekurang-kurangnya 30\% (tiga puluh persen) sesuai dengan ketentuan peraturan perundang-undangan" adalah sebagaimana diatur dalam Pasal 2 ayat (5), Pasal 20, dan Pasal 51 ayat (2) Undang-Undang Nomor 2 Tahun 2008 tentang Partai Politik sebagaimana telah diubah dengan Undang-Undang Nomor 2 Tahun 2011 tentang Perubahan atas Undang-Undang Nomor 2 Tahun 2008 tentang Partai Politik. Lebih lanjut pada Pasal 53 Ayat (2) Undang-Undang Nomor 8 Tahun 2012 tentang Pemilihan Umum Anggota Dewan Perwakilan Rakyat, Dewan Perwakilan Daerah, dan Dewan Perwakilan Rakyat Daerah, menyebutkan "di dalam daftar bakal calon sebagaimana dimaksud pada ayat (1), setiap 3 (tiga) orang bakal calon terdapat sekurang-kurangnya 1 (satu) orang perempuan bakal calon”. Lebih lanjut pada Pasal 55 menyebutkan bahwasannya "daftar bakal calon sebagaimana dimaksud dalam Pasal 53 memuat paling sedikit 30\% (tiga puluh persen) keterwakilan perempuan". Dalam setiap 3 (tiga) bakal calon, bakal calon perempuan dapat ditempatkan pada urutan 1 , atau 2 , atau 3 dan demikian seterusnya, tidak hanya pada nomor urut 3,6, dan seterusnya.

Pada saat Verifikasi Kelengkapan Administrasi Bakal Calon Anggota DPR, DPRD Provinsi dan DPRD Kabupaten/Kota, di Pasal 58 Ayat (1) Komisi 
Pemilihan Umum (KPU) melakukan verifikasi terhadap kelengkapan dan kebenaran dokumen persyaratan administrasi bakal calon anggota DPR dan verifikasi terhadap terpenuhinya jumlah sekurang-kurangnya 30\% (tiga puluh persen) keterwakilan perempuan. Pasal 58 Ayat (2) menyebutkan bahwasannya "KPU Provinsi melakukan verifikasi terhadap kelengkapan dan kebenaran dokumen persyaratan administrasi bakal calon anggota DPRD provinsi dan verifikasi terhadap terpenuhinya jumlah bakal calon sekurang-kurangnya 30\% (tiga puluh persen) keterwakilan perempuan". Pada Pasal 58 Ayat (3) "KPU Kabupaten/Kota melakukan verifikasi terhadap kelengkapan dan kebenaran dokumen persyaratan administrasi bakal calon anggota DPRD kabupaten/kota dan verifikasi terhadap terpenuhinya jumlah bakal calon sekurang-kurangnya $30 \%$ (tiga puluh persen) keterwakilan perempuan". Pasal 59 Ayat (2) berbunyi "dalam hal daftar bakal calon tidak memuat sekurang-kurangnya 30\% (tiga puluh persen) keterwakilan perempuan, maka KPU, KPU Provinsi, dan KPU Kabupaten/Kota memberikan kesempatan kepada partai politik untuk memperbaiki daftar bakal calon tersebut". Dalam bunyi Pasal 62 Ayat (6) menyatakan "KPU, KPU Provinsi, dan KPU Kabupaten/Kota mengumumkan persentase keterwakilan perempuan dalam daftar calon sementara partai politik masing-masing pada media massa cetak harian nasional dan media massa elektronik nasional". Pengumuman persentase keterwakilan perempuan dalam daftar calon sementara dalam ketentuan ini dilakukan sekurang-kurangnya pada 1 (satu) media cetak selama 1 (satu) hari dan pada 1 (satu) media elektronik selama 1 (satu) hari.

Lebih lanjut dalam Pasal 67 Ayat (2) Undang-Undang Nomor 8 Tahun 2012 tentang Pemilihan Umum Anggota Dewan Perwakilan Rakyat, Dewan Perwakilan Daerah, dan Dewan Perwakilan Rakyat Daerah, berbunyi “KPU, KPU Provinsi, dan KPU Kabupaten/Kota mengumumkan persentase keterwakilan perempuan dalam daftar calon tetap partai politik masing-masing pada media massa cetak harian nasional dan media massa elektronik nasional”. Pengumuman persentase keterwakilan perempuan dalam daftar calon tetap dalam ketentuan ini dilakukan sekurang-kurangnya pada 1 (satu) media cetak selama 1 (satu) hari dan pada 1 (satu) media elektronik selama 1 (satu) hari. Lebih lanjut pada Pasal 215 
Ayat b menyebutkan "dalam hal terdapat dua calon atau lebih yang memenuhi ketentuan sebagaimana dimaksud dalam huruf a dengan perolehan suara yang sama, penentuan calon terpilih ditentukan berdasarkan persebaran perolehan suara calon pada daerah pemilihan dengan mempertimbangkan keterwakilan perempuan".

Undang-Undang Nomor 2 Tahun 2008 tentang Partai Politik sebagaimana telah diubah dengan Undang-Undang Nomor 2 Tahun 2011 tentang Perubahan atas Undang-Undang Nomor 2 Tahun 2008 tentang Partai Politik

Sejak Pemilu 2004, melalui Undang-undang Partai Politik No. 31 tahun 2002, telah berubah beberapakali yakni Undang-Undang Nomor 2 Tahun 2008 tentang Partai Politik sebagaimana telah diubah dengan Undang-Undang Nomor 2 Tahun 2011 tentang Perubahan atas Undang-Undang Nomor 2 Tahun 2008 tentang Partai Politik, mengatur perihal keterlibatan perempuan dalam kepengurusan partai politik dan kuota pencalonan legislatif perempuan sebanyak 30\%. Meski upaya penerapan kuota telah dilakukan, namun pada Pemilu 2009 belum menunjukkan angka keberhasilan yang signifi kan karena baru mencapai 18.04\% (101 orang dari 560 orang anggota) keterwakilan perempuan di Dewan Perwakilan Rakyat (DPR). sementara keterwakilan perempuan di Dewan Perwakilan Daerah (DPD) mencapai 26.52\% (35 orang dari 132 orang anggota). Untuk menopang terwujudnya kuato $30 \%$ tersebut perlu pemikiran yang matang dan keseriusan yang penuh bagi para perempuan yang memilih dan meniti karirnya di dunia politik tersebut. Dengan keseriusan dan semangatnya untuk mensosialisasikan sampai ke akar rumput, maka cita-cita pencapaian $30 \%$ itu akan terpenuhi di kompetisi bulan April 2014 nanti.

Negara-negara seperti di eropa pemenuhan hak-hak politik perempuan dilakukan secara incremental, bertahap dan melalui perjuangan yang keras. Hak memilih bagi perempuan yang paling awal di dunia Barat dinikmati oleh perempuan New Zeland. Hanya 10 minggu setelah gubernur Lord Glasgow menandatangani the Electoral Act 1893, sebanyak 109. 461 perempuan New Zeland tercatat menggunakan hak memilihnya pada pemilu 1893. Sudah tentu ini tidak berarti bahwa perempuan Indonesia tidak dihadapkan pada persoalan- 
persoalan sebagaimana banyak perempuan di dunia alami. Dalam bidang politik, persoalan rendahnya partisipasi dan representasi kaum perempuan, terutama di lembaga-lembaga publik, termasuk di parlemen merupakan masalah serius di Indonesia.

Perempuan juga, berdasarkan realita objektif persoalan rendahnya dan buruknya kualitas partisipasi dan representasi merupakan bagian dari persoalan demokrasi Indonesia yang belum selesai dan masih terus mencari bentuk, dan bukan merupakan persoalan perempuan semata-mata. Masih banyak kelompok dalam masyarakat Indonesia dihadapkan pada kedua persoalan ini. Kaum petani, dan nelayan, misalnya, menghadapi masalah ini sama seriusnya dengan kaum perempuan. Demikian pula dengan kaum buruh. Karenanya, persoalan partisipasi dan representasi yang buruk ini harus diselesaikan sebagai agenda politik kolektif sebuah bangsa, bukan dibatasi sebagai medan pergulatan gender situasi inilah yg terjadi di Indonesia.

Dengan adanya konstitusi yang mengatur tentang keterlibatan perempuan dalam kepengurusan partai politik dan kuota pencalonan legislatif perempuan sebanyak 30\%, harapan penulis kepada semua kaum perempuan, tidak bereforia dengan terjaminnya hak itu oleh konstitusi, sehingga hak-hak lainnya yang juga tidak kalah penting terabaikan begitu saja. Salah satu contohnya, bila perempuan yang sudah berkeluarga, bilamana ingin berproses dan ingin mengambil bagian yang jamin konstitusi tersebut, harus dulu menyelesaikan kewajibannya sebagai seorang ibu dan sebagai istri yang baik, mengurus dulu keperluan anak-anaknya, agar anak-anaknya kelak beranjak dewasa menjadi orang terdidik dan menjadi pemimpin yang tangguh serta mengurus dulu kewajibannya sebagai seorang istri. 


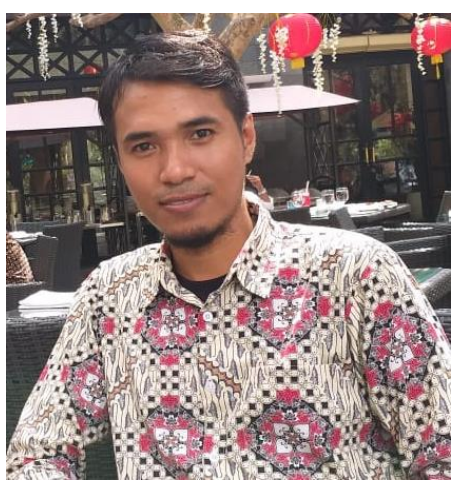

Penulis: M. Jamil, S.H.

Ketua Umum Pusat Studi Mahasiswa Pascasarjana (PUSMAJA) Mbojo-Yogyakarta Periode 2015-2017 | Ketua II Bagian Eksternal Dewan Pimpinan Cabang Perhimpunan Mahasiswa Hukum Indonesia Daerah Istimewa Yogyakarta (DPC PERMAHI DIY) Periode 2012-2014

\section{Ful Sumber Tulisan:}

M. Jamil, "Undang-Undang dan Jaminan Politik Perempuan”, Majalah NUSANTARA IKPMDI-Yogyakarta, diterbitkan melalui Dinas Pendidikan Pemuda dan Olahraga (Disdikpora) Daerah Istimewa Yogyakarta, edisi MaretApril 2014, lihat Halaman 16-19. 